\title{
INCOME STRUCTURE OF COMMUNES OF THE ŚWIĘTOKRZYSKIE VOIVODSHIP IN 2009-2018
}

\author{
Pietrowski Wojciech ${ }^{1}$
}

\begin{abstract}
The issue of this paper concerns the income of municipalities and their structures. The research topic is not a new issue, it has been raised in the literature. However, it is justified to take up this subject due to the dynamics of this phenomenon and outdated research results. Undertaking the subject matter is also justified by the variable economic situation affecting the achieved revenues of municipalities. The article aims to analyze the income structure of communes in the Świętokrzyskie Province. The author will also refer to changes in the structure of income, the dominant categories of income over the decade under review. When reading the literature, no similar research was found covering the Świętokrzyskie region. The analysis was based on data from the Local Data Bank regarding municipalities in the Świętokrzyskie Province. The formatted databases included municipal incomes divided by a source. During the study, all municipalities from the Świętokrzyskie Province were taken into account, along with Kielce - a city with poviat status. In total 102 units were included in the study. The research period covered the years 2009-2018 and resulted from the availability of statistical data and a correspondingly long period of analysis. While discussing the phenomenon, data on individual years were used, and the average share of a given category in the period under consideration was determined. Due to the attention paid to the structure of income at work, the data was presented as a percentage. The obtained data, expressed in terms of value, was developed by transforming it into a percentage share. The average values for the research period were determined by taking the average value from the sum of values of individual years. The author does not refer to data other than the accepted one, instead he focuses on analyzing changes in the structure. Differentiation of particular categories of income is visible. Comparing the data at the country and region level, the deviations are not large. However, by looking at the data of individual units, one can see their diversity under this account. Despite the presentation in the main three areas (own revenues, subsidies and general subsidy) of their detailed elements, large differences in the share between individual taxes and subsidies can be seen. The average income structure in communes in the Świętokrzyskie voivodship does not differ significantly from the national trend. In communes with the highest share of own revenues, their amount is determined by property tax. The structure presented in this way, its diversity in the Świętokrzyskie region is a premise for comparing the analyzed data on individual municipalities with indicators from other areas.
\end{abstract}

Key words: commune income, commune own income, general subsidy, grants, tax revenues, shares in taxes.

JEL Classification: $\mathrm{H} 20$

\section{Introduction}

The tasks of the local government unit (LGU) can only be carried out if they are properly financed. Without properly secured means, it is not possible for local government units to function properly. The area providing such security is the entity's income. It provides the basis for the implementation of tasks assigned to local government units.

The issue of this paper concerns the income of municipalities and their structures. The research topic is not a new issue, it has been raised in the literature. However, it is justified to take up this subject due to the

Corresponding author:

${ }^{1}$ Jan Kochanowski University in Kielce, Poland.

ORCID: https://orcid.org/0000-0002-5362-3768

E-mail: wojciech.pietrowski@gmial.com dynamics of this phenomenon and outdated research results. Undertaking the subject matter is also justified by the variable economic situation affecting the achieved revenues of municipalities.

The article aims to analyze the income structure of communes in the Świętokrzyskie Voivodship. The author will also refer to changes in the structure of income, the dominant categories of income over the decade under review. When reading the literature, no similar research has been found covering the Świętokrzyskie region.

The analysis was based on data from the Local Data Bank regarding municipalities in the Świętokrzyskie 
Voivodship. The formatted databases included municipal incomes divided by a source. During the study, all municipalities from the Świętokrzyskie Province were taken into account, along with Kielce - a city with poviat status. In total, 102 units were included in the study.

The research period covered the years 2009-2018 and resulted from the availability of statistical data and a correspondingly long period of analysis. While discussing the phenomenon, data on individual years were used, and the average share of a given category in the period under consideration was determined. Due to the attention paid to the structure of income at work, the data was presented as a percentage. The obtained data, expressed in terms of value, was developed by transforming it into a percentage share. The average values for the research period were determined by taking the average value from the sum of values of individual years. The author does not refer to data other than the accepted one, instead he focuses on analyzing changes in the structure.

\section{Income characteristics}

Local self-government's revenues are part of its budget adopted for the calendar year. The amount of planned budget revenues for a given year is specified in the budget resolution ${ }^{1}$.

Local self-government's budget revenues are a source of information on the shape of its wealth and affect the directions of spending funds. They can be classified in different ways. We can talk about the division into compulsory and optional incomes. Obligatory revenues include: own revenues, general subsidy and earmarked subsidies from the state budget. Optional revenues include: funds from foreign sources, non-returnable funds, funds from the EU budget and other funds specified in provisions separate from the Act on the income of local government units. Another division of local selfgovernment's income is into current and property income. Property income includes subsidies and funds allocated for investments, income from the sale of assets, income from the transformation of perpetual usufruct right into ownership. Other income is recognized as current income. Another classification divides the revenues of local government units from the perspective of their sources of origin, separating own and supplementary income.
Supplementary income includes general subsidies and grants $^{2}$. The Act divides the income of local government units into ${ }^{3}$ :

- own revenues;

- general subsidy;

- earmarked subsidies from the state budget.

It also indicates other possible sources of income $e^{4}$. In the paper for the purposes of the analysis, the abovementioned division of income of local government units indicated in the Act was adopted.

As part of our own revenues we distinguish, among others :

- revenues from taxes (on real estate, agricultural, forestry, on means of transport, income from individuals, paid in the form of a tax card, on inheritances and donations, on civil law transactions);

- income obtained by municipal budgetary units and payments from municipal budgetary establishments;

- income from the commune's assets;

- inheritances, bequests and donations to the commune.

Special-purpose subsidies from the state budget may be granted for ${ }^{6}$ :

- government administration tasks and other tasks commissioned by statutes;

- tasks implemented under agreements;

- financing or co-financing of own tasks;

- implementation of tasks resulting from international agreements;

- removing immediate threats to public security and order.

Budget revenues are an important element of the local government finance system, as they affect the ability of local government units to perform public tasks ${ }^{7}$.

The general subsidy for municipalities consists of the equalization part, the balancing part and the educational part. It is an important component of public finances in terms of the analysis of state budget expenditure and the income of local government units. The system of subsidizing the local government sector involves a significant amount of public funds ${ }^{8}$. The general subsidy's performance of its income and compensatory function is determined by objective and stable criteria for its granting. It is also important to emphasize the continuing increase in the importance of the educational subsidy due to all municipalities in relation to the compensatory and balancing part ${ }^{9}$.

\footnotetext{
${ }^{1}$ Ustawa z dnia 27 sierpnia 2009 roku o finansach publicznych (Dz.U. $2009 \mathrm{Nr} 157$ poz. 1240 z późn. zm.), art. 211 i 212.

2 M. Dworakowska, Dochody budżetowe jednostek samorzadu terytorialnego z perspektywy absorpcji funduszy unijnych, Optimum. Economic Studies Nr 3(93), Białystok 2018, s. 54-56.

${ }^{3}$ Ustawa z dnia 13 listopada 2003 r. o dochodach jednostek samorzadu terytorialnego (Dz.U. 2020 poz. 23, 374) Art. 3, pkt. 1.

${ }^{4}$ op. cit., Art. 3, pkt. 3.

${ }^{5}$ op. cit., Art. 4, pkt. 1.

op. cit., Art. 8, pkt. 1.

${ }^{6}$ M. Dworakowska, Dochody budżetowe jednostek..., op. cit., p. 61.

${ }^{7}$ A. Sekuła, System subwencjonowania jednostek samorzadu terytorialnego w Polsce: dysfunkcje i pożądane kierunki racjonalizacji, Politechnika Gdańska, Gdańsk 2016, p. 244.

${ }^{8} \mathrm{~J}$. Szołono-Koguc, Subwencja ogólna jako instrument wsparcia transferowego samorządu gminnego, Prace Naukowe Uniwersytetu.

${ }_{9}^{9}$ Ekonomicznego we Wrocławiu, nr 485 Relacje fiskalne państwo - samorzad terytorialny, Wrocław 2017, p. 470.
} 
Subsidies are a source of funding for tasks that must be carried out by a local government unit. Due to their desirability, they limit the free spending of funds, at the same time ordering them to account for their use $\mathrm{e}^{10}$.

Budget revenues are an important element of the local government finance system, as they affect the ability of local government units to perform public tasks ${ }^{11}$. Local government has the ability to implement its tasks when it has stable and efficient sources of its own revenues. The share of own income has a positive effect on the independence of decision making. These revenues are characterized by the highest stability, predictability and the possibility of direct impact on their amount. The share of own revenues in total revenues is one of the determinants of financial independence of the commune. The structure of municipalities' revenues in the voivodship and the country is presented in Charts 1 and 2, taking into account the city with poviat rights.

The above chart presents the income structure of communes of the Świętokrzyskie voivodship in selected years of the examined period. The structure of income in the period under review slightly changed, which is visible mainly in 2018 where the increase in the level of subsidies by $10 \%$ was accompanied by a decrease in the level of own revenues and general subsidy.

Own revenues in a local government unit should constitute a financial base, which should reflect their highest share in the total income structure ${ }^{12}$.

Comparing data from the Świętokrzyskie region (Figure 1) to data from the whole country (Figure 2),

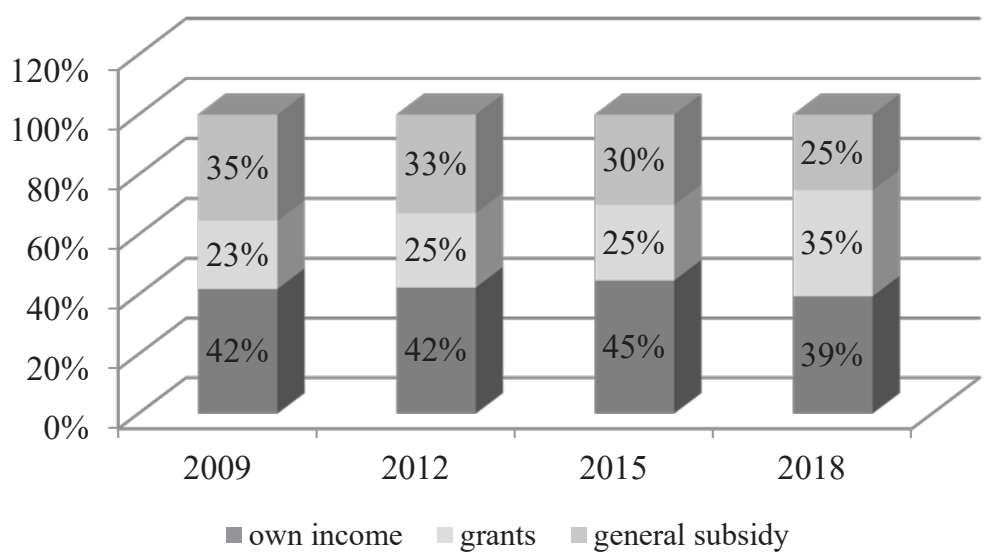

Diagram 1. The structure of municipalities' revenues in the Świętokrzyskie voivodship in the years 2009-2018

Source: own study based on data from Bank Danych Lokalnych GUS

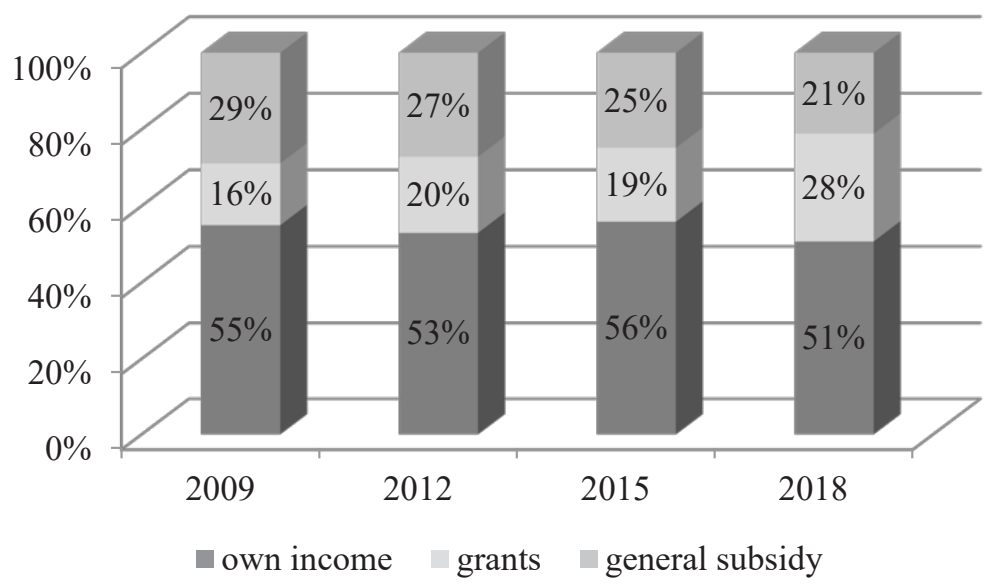

Diagram 2. The structure of municipalities' revenues in Poland provinces in the years 2009-2018

Source: own study based on data from Bank Danych Lokalnych GUS

\footnotetext{
${ }^{10} \mathrm{~K}$. Owsiak, Kontrowersje wokót dotacji celowych dla jednostek samorządu terytorialnego, Prace Naukowe Uniwersytetu Ekonomicznego we Wrocławiu, nr 485 Relacje fiskalne państwo - samorząd terytorialny, Wrocław 2017, p. 341.

${ }^{11}$ M. Dworakowska, Dochody budżetowe jednostek ..., op. cit., p. 61.

${ }^{12}$ M. Dworakowska, Dochody budżetowe jednostek..., op. cit., p. 55.
} 


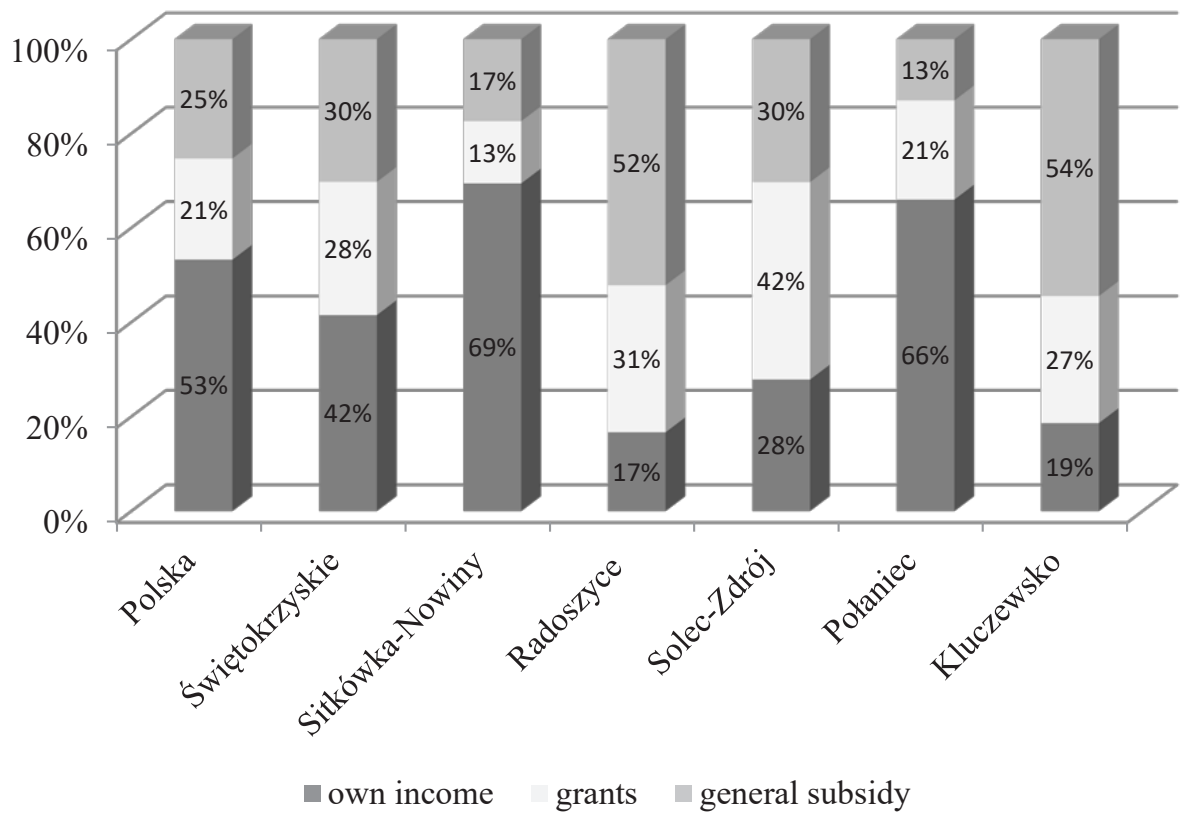

Diagram 3. Income structure in selected communes of the Świętokrzyskie voivodship

Source: own study based on data from Bank Danych Lokalnych GUS

we can state the existing analogies. Namely, it is the advantage of own revenues and the increase in the share of subsidies in 2018. However, there is an approximate $10 \%$ advantage of the share of own revenues in the revenues of municipalities throughout the country. Own revenues are the dominant source of municipalities' revenues, which constitute about $40 \%$ of municipalities' revenues in the Świętokrzyskie voivodship, and over $50 \%$ of municipalities' revenues in the country.

Chart 3 shows the structure of municipalities' income in the country, region and selected communes from the region with the largest and smallest shares of individual income categories. The structure diversity is not visible in relation to the average country and voivodship. However, if we look at the income structure of individual municipalities, the situation changes significantly. The difference in the share of own income between the municipality with the highest share (Sitkówka-Nowiny) and the lowest (Radoszyce) is 52\%. It is true that these are extreme cases, and their scale in the studied region is not so large. The smaller variation is represented by subsidies, in which the difference between the extreme communes (Solec-Zdrój and Sitkówka-Nowiny) is $29 \%$, while in the case of the general subsidy it is $41 \%$ (Kluczewsko and Połaniec). Referring to changes in the structure in individual years of the audited period, they vary in different municipalities. Due to the very large volume of databases (102 units and 10 years), the conclusions of some observations will be presented only in a descriptive form.

\section{Structure of own income, subsidies and general subsidy}

Own income is a special type of commune income. It decides on the degree and scope of financial independence of the entity. The appropriate level of own income provides freedom in shaping financial policy, allows to dispose of the assets independently, which translates into its stable development ${ }^{13}$.

Table 1 shows the division of communes in the Świętokrzyskie Voivodship due to the share of own revenues in revenues. A division into 5 groups including $20 \%$ ranges was used. The largest number of communes was in the group with a share of $21 \%$ to $40 \%-70$ communes per 102 communes. In the ranges above $40 \%$, municipalities were in the majority, 21 communes in total. The lowest share of own revenues occurred in Mniów, Radoszyce and Slupia Konecka amounting to $17 \%$. For 11 municipalities, the share of own revenues in revenues is less than $20 \%$.

In order to compare the spatial distribution of municipalities with the data contained in Table 1, Figure 1 was developed, in which municipalities were presented, taking into account the division into groups already cited in the paper.

As shown in the figure, the share of own revenues in terms of the distribution of municipalities on the map of the region is varied. It should be noted, however, that 6 out of 11 communes with the lowest share of own revenues are located in the northwestern part of the region, bordering each other. 3 communes with the highest share of own revenues, i.e., Sitkówka-

\footnotetext{
${ }^{13}$ P. Dziekański, Wykorzystanie wskaźnika syntetycznego do oceny poziomu rozwoju samorządu na przykładzie gmin wiejskich województwa świętokrzyskiego, [in:] Determinanty rozwoju Polski, S. Owsiak (ed.), PTE, Warszawa 2015, p. 261.
} 
Table 1

Average share of own revenues in the revenues of communes of the Świętokrzyskie voivodship in the years 2009-2018

\begin{tabular}{|c|c|c|}
\hline No. & $\begin{array}{l}\text { average share of own income } \\
\text { in the commune's income }\end{array}$ & $\begin{array}{l}\text { name of the commune commune (own income in \%); } \\
\text { number of communes }\end{array}$ \\
\hline 1 & 2 & 3 \\
\hline 2 & from $0 \%$ to $20 \%$ & $\begin{array}{l}\text { Mniów (17), Radoszyce (17), Słupia Konecka (17), Klimontów (18), Pawłów (18), Bieliny (19), } \\
\text { Smyków (19), Waśniów (19), Eubnice (19), Kluczewsko (19), Łopuszno (20) } \\
11 \text { communies }\end{array}$ \\
\hline 3 & from $21 \%$ to $40 \%$ & $\begin{array}{l}\text { Oksa (21), Gowarczów (21), Fałków (22), Iwaniska (22), Imielno (23), Górno (23), Lipnik (23), } \\
\text { Tarłów (23), Samborzec (23), Wilczyce (23), Mirzec (23), Wiślica (24), Sobków (24), Bejsce (24), } \\
\text { Bodzentyn (24), Złota (24), Brody (24), Secemin (24), Nowy Korczyn (25), Pacanów (25), Nowa } \\
\text { Słupia (25), Raków (25), Gnojno (26), Nagłowice (26), Słupia (26), Czarnocin (26), } \\
\text { Ruda Maleniecka (26), Michałów (26), Koprzywnica (26), Łoniów (26), Pierzchnica (27), } \\
\text { Ćmielów (27), Bliżyn (27), Moskorzew (27), Radków (27), Solec Zdrój (28), Opatowiec (28), } \\
\text { Sadowie (28), Zawichost (28), Wodzisław (29), Łagów (29), Kije (29), Skalbmierz (30), Dwikozy } \\
\text { (30), Łączna (30), Skarżysko Kościelne (30), Szydłów (30), Chmielnik (31), Strawczyn (31), } \\
\text { Stąporków (31), Obrazów (31), Wąchock (31), Rytwiany (31), Stopnica (32), Daleszyce (32), } \\
\text { Kunów (32), Działoszyce (32), Bogoria (32), Baćkowice (33), Bałtów (33), Miedziana Góra (34), } \\
\text { Wojciechowice (34), Bodzechów (34), Oleśnica (35), Kazimierza Wielka (37), Zagnańsk (37), } \\
\text { Krasocin (38), Chęciny (39), Opatów (40), Osiek (40) } \\
70 \text { communies }\end{array}$ \\
\hline 4 & from $41 \%$ to $60 \%$ & $\begin{array}{c}\text { Staszów (42), Sędziszów (43), Jędrzejów (43), Piekoszów (43), Suchedniów (44), Tuczępy (45), } \\
\text { Małogoszcz (45), Morawica (45), Masłów (46), Włoszczowa (46), Busko-Zdrój (49), } \\
\text { Pińczów (50), Końskie (52), Kielce (52), Ożarów (55), Ostrowiec Świętokrzyski (55), } \\
\text { Starachowice (55), Skarżysko-Kamienna (60) } \\
18 \text { communies }\end{array}$ \\
\hline 5 & from $61 \%$ to $80 \%$ & $\begin{array}{c}\text { Sandomierz (61), Połaniec (66), Sitkówka-Nowiny (69) } \\
3 \text { communies }\end{array}$ \\
\hline 6 & from $81 \%$ to $100 \%$ & $\begin{array}{c}- \\
0 \text { commune }\end{array}$ \\
\hline
\end{tabular}

Source: own study based on data from Bank Danych Lokalnych GUS

Nowiny, Połaniec and Sandomierz are significantly separated from each other. The reasons for the share of own revenues at the level of over $60 \%$ in the indicated communes will be discussed further in the paper.

The rest of the paper is based on the basic division of income into own revenues, subsidies and general subsidy. A comparison of revenues at the level of communes in the Świętokrzyskie voivodship and communes throughout the country was presented. The following Table presents the share of individual categories of income in total own revenues.
As part of own revenues, the highest share is represented by taxes constituting state budget revenues, i.e., from personal income tax and corporate income tax. Tax revenues including agricultural tax, forest tax, property tax, tax on means of transport, tax on civil law transactions are another category of own income constituting about 30\% share in the income of municipalities both in the Świętokrzyskie voivodship and the whole country. The share of other own income groups in total income does not exceed $10 \%$. Table 2 shows a sustained level of tax revenue, which is

Table 2

Structure of communes' own revenues in the Świętokrzyskie voivodship and Poland in selected years

\begin{tabular}{|c|c|c|c|c|c|c|c|c|}
\hline \multirow{2}{*}{ Own income } & \multicolumn{4}{|c|}{ Świętokrzyskie } & \multicolumn{4}{|c|}{ Poland } \\
\hline & 2009 & 2012 & 2015 & 2018 & 2009 & 2012 & 2015 & 2018 \\
\hline $\begin{array}{l}\text { tax revenues - determined and charged } \\
\text { on the basis of separate acts }\end{array}$ & $33 \%$ & $33 \%$ & $33 \%$ & $31 \%$ & $29 \%$ & $30 \%$ & $28 \%$ & $27 \%$ \\
\hline proceeds from fees & $1 \%$ & $3 \%$ & $7 \%$ & $6 \%$ & $2 \%$ & $2 \%$ & $6 \%$ & $6 \%$ \\
\hline income from assets & $9 \%$ & $9 \%$ & $6 \%$ & $5 \%$ & $8 \%$ & $9 \%$ & $8 \%$ & $7 \%$ \\
\hline $\begin{array}{l}\text { shares in taxes constituting total state } \\
\text { budget revenues }\end{array}$ & $37 \%$ & $36 \%$ & $38 \%$ & $43 \%$ & $40 \%$ & $39 \%$ & $40 \%$ & $45 \%$ \\
\hline receipts from services & $5 \%$ & $6 \%$ & $6 \%$ & $6 \%$ & $6 \%$ & $7 \%$ & $6 \%$ & $5 \%$ \\
\hline other income & $15 \%$ & $13 \%$ & $10 \%$ & $9 \%$ & $14 \%$ & $13 \%$ & $11 \%$ & $10 \%$ \\
\hline
\end{tabular}

Source: own study based on data from Bank Danych Lokalnych GUS 


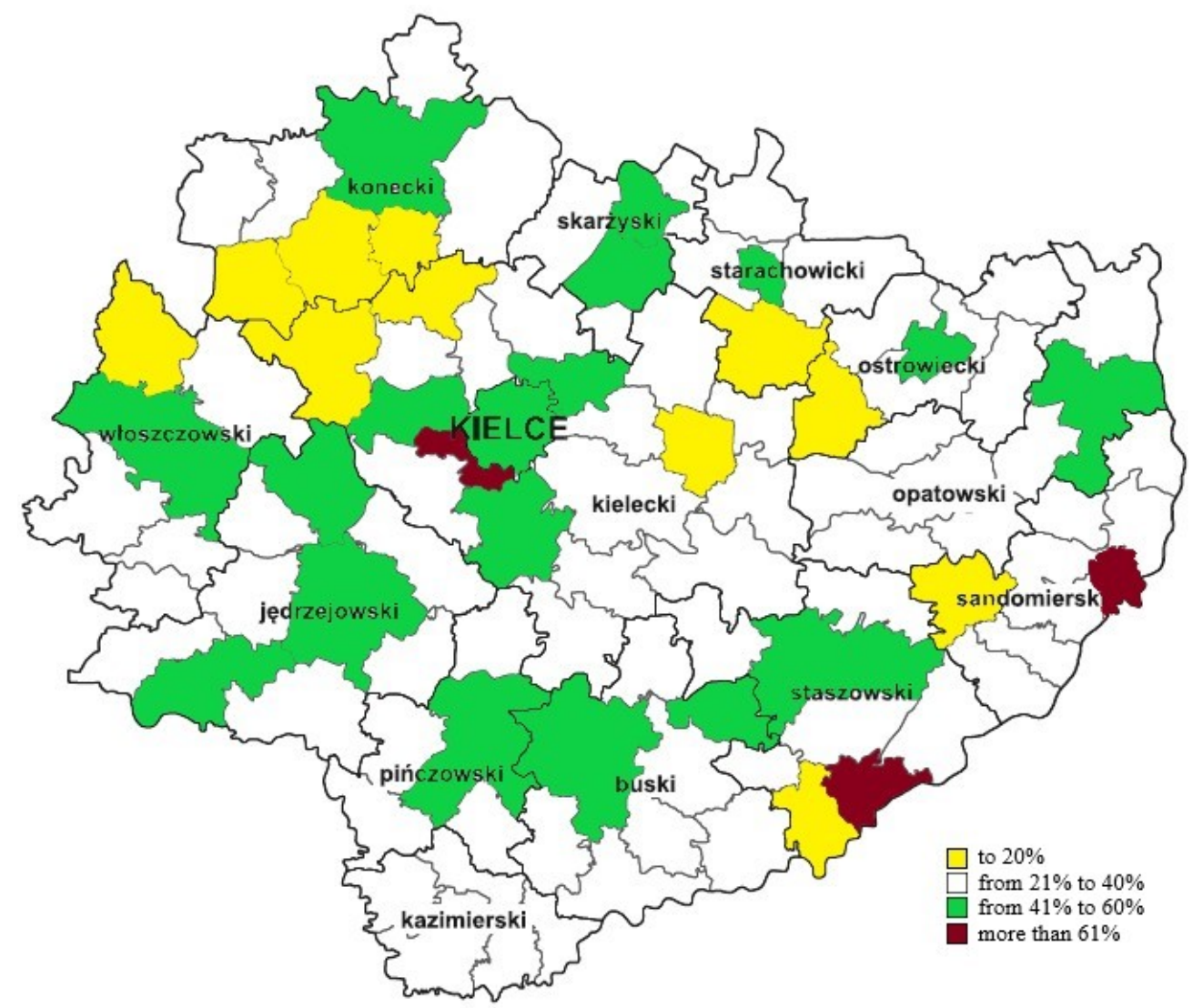

Figure 1. Spatial differentiation of the share of own revenues of communes of the Świętokrzyskie voivodship in total revenues (on average in the years 2009-2018)

Source: own study

slightly higher in the region studied than in the whole country. The share of taxes constituting state budget revenues is gradually increasing, especially in 2018. On the national scale, this category of own revenues has a higher share than in relation to the region.
The figure above presents the share of individual categories of income in the own revenues of communes of the Świętokrzyskie Province. The \% share was presented as average income from 2009-2018. It confirms the data contained in Table 2. Tax revenues

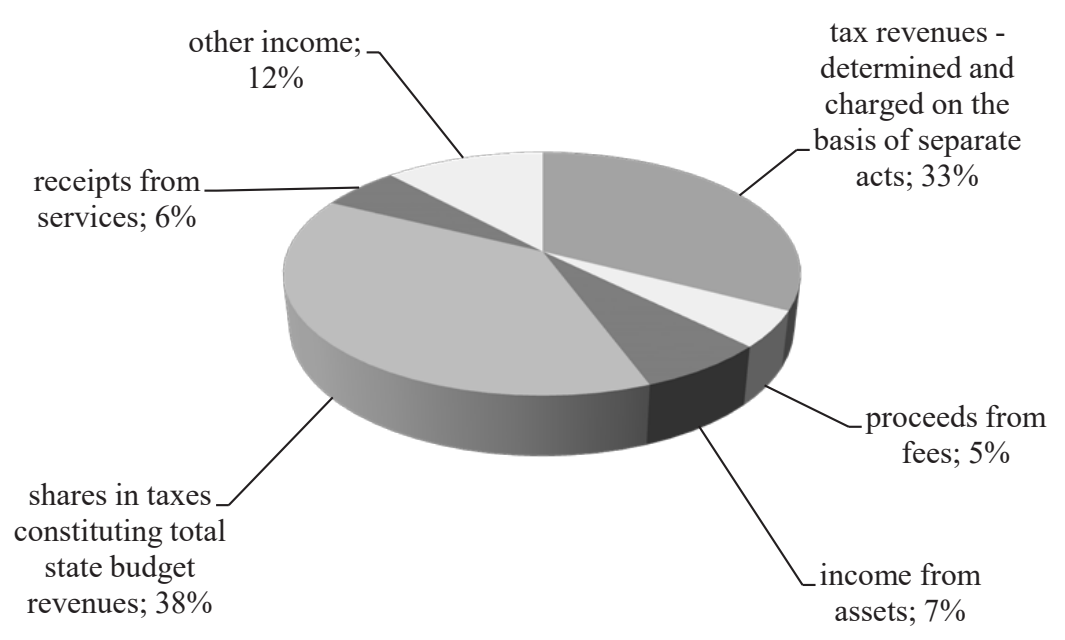

Figure 2. Structure of own revenues of communes in the Świętokrzyskie voivodship (on average from 2009-2018)

Source: own study based on data from Local Data Base GUS 
and shares in taxes constitute over $70 \%$ of the revenues of communes of the Świętokrzyskie voivodship in the analyzed period, determining their decisive role in shaping the revenues of communes.

Table 3 presents a detailed structure of two categories of income deciding on the amount of own revenues of communes. Analyzing the data contained in the table above, we can see a clear advantage of personal income tax and real estate tax in the structure of own income. Other taxes have only a few percent share in income. One can also state a systematic increase in the share of personal income tax, which increased in the 10-year period by approx. $6 \%$. The share structure of the two main categories of income overlaps at the regional and national levels. The $0 \%$ share of personal income tax paid in the form of tax cards results from the applied rounding of the percentage share to whole numbers. In the case of the Połaniec and Sitkówka-Nowiny municipalities, real estate tax receipts account for over $50 \%$ of revenues, referring to the Sandomierz commune the structure of own revenues is similar to the regional and national average.

The structure of targeted subsidies is discussed below. Table 4 presents the percentage share of earmarked subsidies in the revenues of municipalities.
Target subsidies from the state budget for government administration tasks have the largest share in the revenues of municipalities under targeted subsidies.

In the years 2009, 2012 and 2015 they remained at a similar level, while in 2018 the share of this type of subsidies in the revenues of municipalities more than doubled. These changes can be related to the "Family 500 plus" program introduced in 2017 and its significant share in the state budget expenditure on meeting social need $s^{14}$. Special-purpose subsidies from the state budget for own tasks remain at a similar level during the period considered. Subsidies paragraphs 200, 620 and subsidies paragraphs 205, 625 concern in particular funds under programs financed with the participation of the European funds. As part of the financial perspective 2014-2020, paragraphs 205 and 625 have been separated for local government units acting as beneficiaries ${ }^{15}$.

The literature on the subject often emphasizes the aspect of treating subsidies as instruments of state interference in the activities of local government units. The high share of subsidies in the total income structure indicates a decrease in income independence. It should also be noted that there is considerable discretion regarding the amount of subsidies awarded due to the

Table 3

The share of selected categories in the own revenues of communes in the Świętokrzyskie voivodship and Poland

\begin{tabular}{|c|c|c|c|c|c|c|c|c|c|}
\hline \multirow{2}{*}{\multicolumn{2}{|c|}{ Own income }} & \multicolumn{4}{|c|}{ Świętokrzyskie } & \multicolumn{4}{|c|}{ Poland } \\
\hline & & 2009 & 2012 & 2015 & 2018 & 2009 & 2012 & 2015 & 2018 \\
\hline \multirow{6}{*}{$\begin{array}{c}\text { tax revenues - } \\
\text { determined and } \\
\text { charged on the basis } \\
\text { of separate acts }\end{array}$} & agricultural tax & $3 \%$ & $3 \%$ & $3 \%$ & $3 \%$ & $2 \%$ & $2 \%$ & $2 \%$ & $1 \%$ \\
\hline & forest tax & $0 \%$ & $0 \%$ & $0 \%$ & $0 \%$ & $0 \%$ & $0 \%$ & $0 \%$ & $0 \%$ \\
\hline & property tax & $25 \%$ & $26 \%$ & $27 \%$ & $24 \%$ & $22 \%$ & $24 \%$ & $23 \%$ & $22 \%$ \\
\hline & tax on means of transport & $2 \%$ & $2 \%$ & $2 \%$ & $2 \%$ & $1 \%$ & $1 \%$ & $1 \%$ & $1 \%$ \\
\hline & tax on civil law transactions & $2 \%$ & $2 \%$ & $2 \%$ & $2 \%$ & $3 \%$ & $2 \%$ & $2 \%$ & $3 \%$ \\
\hline & $\begin{array}{l}\text { business tax on natural persons, } \\
\text { paid in the form of tax cards }\end{array}$ & - & $0 \%$ & $0 \%$ & $0 \%$ & - & $0 \%$ & $0 \%$ & $0 \%$ \\
\hline \multirow{2}{*}{$\begin{array}{c}\text { shares in taxes } \\
\text { constituting total } \\
\text { state budget revenues }\end{array}$} & income tax from individuals & $34 \%$ & $34 \%$ & $36 \%$ & $41 \%$ & $37 \%$ & $36 \%$ & $37 \%$ & $42 \%$ \\
\hline & corporate tax & $4 \%$ & $2 \%$ & $2 \%$ & $2 \%$ & $4 \%$ & $3 \%$ & $3 \%$ & $3 \%$ \\
\hline
\end{tabular}

Source: own study based on data from Bank Danych Lokalnych GUS

Table 4

Structure of the share of grants in the revenues of communes of the Świętokrzyskie voivodship and Poland in selected years

\begin{tabular}{|c|c|c|c|c|c|c|c|c|}
\hline \multirow{2}{*}{ Grants } & \multicolumn{4}{|c|}{ Świętokrzyskie } & \multicolumn{4}{|c|}{ Poland } \\
\hline & 2009 & 2012 & 2015 & 2018 & 2009 & 2012 & 2015 & 2018 \\
\hline $\begin{array}{l}\text { earmarked grants from the state budget for } \\
\text { government administration tasks }\end{array}$ & $31 \%$ & $29 \%$ & $27 \%$ & $60 \%$ & $18 \%$ & $17 \%$ & $15 \%$ & $38 \%$ \\
\hline earmarked grants from the state budget for own tasks & $12 \%$ & $10 \%$ & $13 \%$ & $12 \%$ & $6 \%$ & $6 \%$ & $7 \%$ & $6 \%$ \\
\hline grants $\$ S \$ 200,620$ & $10 \%$ & $18 \%$ & $15 \%$ & $1 \%$ & $3 \%$ & $13 \%$ & $10 \%$ & $1 \%$ \\
\hline grants $\$ \$ 205,625$ & - & - & $0 \%$ & $1 \%$ & - & - & $0 \%$ & $8 \%$ \\
\hline
\end{tabular}

Source: own study based on data from Bank Danych Lokalnych GUS

\footnotetext{
${ }^{14}$ A. Rączaszek, W. Pietrowski, Wydatki społeczne w budżetach Jednostek Samorządu Terytorialnego województwa śląskiego w latach 2002-2017, [in:], Problemy finansów w obliczu nowych wyzwań gospodarki (red.) M. Sosnowski, UE we Wrocławiu, Wrocław 2019 , p. 56.

${ }^{15}$ Rozporządzenie Ministra Finansów z dnia 16 grudnia 2014 roku zmieniajace rozporządzenie w sprawie szczegótowej klasyfikacji dochodów, wydatków, przychodów i rozchodów oraz środków pochodzacych ze źródeł zagranicznych (Dz.U. 2014, poz. 1952), par. 1, ust. 2, lit. i, 1.
} 


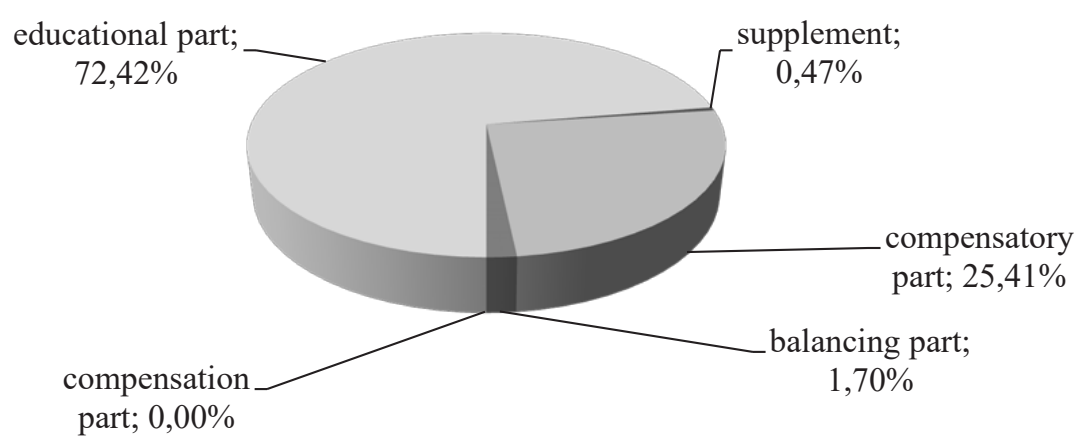

Figure 3. Structure of the general subsidy of communes of the Świętokrzyskie voivodship (on average from 2009-2018)

Source: own study

lack of legal regulations. However, it has an impact on the uniform nature of the economic policy pursued throughout the country ${ }^{16}$.

The last of the analyzed categories of municipal revenues is the general subsidy. The average subsidy structure over the period considered is shown in Figure 3.

The general subsidy in over $70 \%$ consists of the educational part, the next element is the compensatory part over $25 \%$. However, the share of balancing, supplementing and compensating parts is negligible. It can therefore be said that the general subsidy mainly covers the maintenance of educational establishments in communes.

\section{Conclusions}

The data presented illustrate the structure of own revenues, subsidies and general subsidies, as well as their changes during the period considered. Differentiation of particular categories of income is visible. Comparing the data at the country and region level, the deviations are not large. However, by looking at the data of individual units, one can see their diversity under this account. Despite the presentation in the main three areas (own revenues, subsidies and general subsidy) of their detailed elements, large differences in the share between individual taxes and subsidies can be seen. The average income structure in communes in the Świętokrzyskie voivodship does not differ significantly from the national trend. In communes with the highest share of own revenues, their amount is determined by property tax. The structure presented in this way, its diversity in the Świętokrzyskie region is a premise for comparing the analyzed data on individual municipalities with indicators from other areas.

\section{References:}

Determinanty rozwoju Polski, S. Owsiak (red.), PTE, Warszawa 2015.

Optimum. Economic Studies Nr 3(93), Białystok 2018.

Prace Naukowe Uniwersytetu Ekonomicznego we Wrocławiu, nr 485 Relacje fiskalne państwo - samorzad terytorialny, Wrocław 2017.

Problemy finansów w obliczu nowych wyzwań gospodarki (red.) M. Sosnowski, UE we Wrocławiu, Wrocław 2019.

Rozporządzenie Ministra Finansów z dnia 16 grudnia 2014 roku zmieniające rozporządzenie w sprawie szczegótowej klasyfikacji dochodów, wydatków, przychodów i rozchodów oraz środków pochodzących ze źródeł zag ranicznych (Dz.U. 2014, poz. 1952).

Sekuła A., System subwencjonowania jednostek samorzadu terytorialnego $w$ Polsce: dysfunkcje i pożadane kierunki racjonalizacji, Politechnika Gdańska, Gdańsk 2016.

Studia Ekonomiczne. Zeszyty Naukowe Uniwersytetu Ekonomicznego w Katowicach, Nr 345, Katowice 2017.

Ustawa z dnia 13 listopada 2003 r. o dochodach jednostek samorządu terytorialnego (Dz.U. 2020 poz. 23, 374).

Ustawa z dnia 27 sierpnia 2009 roku o finansach publicznych (Dz.U. 2009 Nr 157 poz. 1240 z późn. zm.).

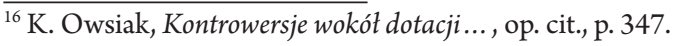

